\title{
Administration of inhaled noble and other gases after cardiopulmonary resuscitation : A systematic review
}

\section{Alshami, Abbas}

2020-10

Alshami , A , Einav , S , Skrifvars , M B \& Varon , J 2020 , ' Administration of inhaled noble and other gases after cardiopulmonary resuscitation : A systematic review ' , American Journal of Emergency Medicine , vol. 38 , no. 10 , pp. 2179-2184 . https://doi.org/10.1016/j.ajem.2020.06.066

http://hdl.handle.net/10138/329677

https://doi.org/10.1016/j.ajem.2020.06.066

cc_by_nc_nd

acceptedVersion

Downloaded from Helda, University of Helsinki institutional repository.

This is an electronic reprint of the original article.

This reprint may differ from the original in pagination and typographic detail.

Please cite the original version. 
Title: "Administration of Inhaled Noble and Other Gases after Cardiopulmonary Resuscitation: A Systematic Review"

Authors:

\author{
Abbas Alshami, MD \\ Medical Resident, \\ Jersey Shore University Medical Center, \\ Neptune, New Jersey, USA \\ Research Assistant, \\ Dorrington Medical Associates, PA \\ Houston, Texas, USA
}

\title{
Sharon Einav, MD, MSc
}

Associate Professor of Anesthesiology and Intensive Care Medicine Intensive Care Unit of the Share Zedek Medical Center and Faculty of Medicine of the Hebrew University

Jerusalem, Israel

\section{Markus B Skrifvars, MD, PhD, FCICM, EDIC}

Professor of Pre-hospital Emergency Medicine

Department of Emergency Care and Services

Helsinki University Hospital and University of Helsinki

Helsinki, Finland 
Joseph Varon, MD, FACP, FCCP, FCCM, FRSM

Professor of Acute and Continuing Care,

The University of Texas Health Science Center at Houston

Clinical Professor of Medicine, the University of Texas Medical Branch at Galveston

Chief of Critical Care Services, United Memorial Medical Center /

United General Hospital, Houston, Texas, USA

\section{Address for Correspondence:}

Prof. Joseph Varon, MD, FACP, FCCP, FCCM, FRSM

2219 Dorrington Street

Houston, Texas 77030, USA

Tel: +1-713-669-1670

Fax: +1-713-669-1671

Jvaron@roamer.net

Conflicts of Interest: Markus B Skrifvars would like to declare he received speakers' fees from BARD Medical (Ireland) and research funding from GE Healthcare. The remaining authors have disclosed that they do not have any conflicts of interest. 


\section{ABSTRACT:}

Objective: Inhalation of noble and other gases after cardiac arrest (CA) might improve neurological and cardiac outcomes. This article discusses up-to-date information on this novel therapeutic intervention.

Data Sources: CENTRAL, MEDLINE, online published abstracts from conference proceedings, clinical trial registry clinicaltrials.gov, and reference lists of relevant papers were systematically searched from January 1960 till March 2019.

Study Selection: Preclinical and clinical studies, irrespective of their types or described outcomes, were included.

Data Extraction: Abstract screening, study selection, and data extraction were performed by two independent authors. Due to the paucity of human trials, risk of bias assessment was not performed.

Data Synthesis: After screening 281 interventional studies, we included an overall of 27. Only, xenon, helium, hydrogen, and nitric oxide have been or are being studied on humans. Xenon, nitric oxide, and hydrogen show both neuroprotective and cardiotonic features, while argon and hydrogen sulfide seem neuroprotective, but not cardiotonic. Most gases have elicited neurohistological protection in preclinical studies; however, only hydrogen and hydrogen sulfide appeared to preserve CA1 sector of hippocampus, the most vulnerable area in the brain for hypoxia.

Conclusion: Inhalation of certain gases after CPR appears promising in mitigating neurological and cardiac damage and may become the next successful neuroprotective and cardiotonic interventions.

Keywords: Noble gases; Cardiopulmonary resuscitation; Heart arrest; Neuroprotection; Cardioprotection; Nitric oxide; Hydrogen. 


\section{BACKGROUND:}

Improvements in emergency care systems and the development of public health initiatives promoting quality cardiopulmonary resuscitation (CPR) have resulted in a dramatic increase in initial return of spontaneous circulation (ROSC) and survival rates after cardiac arrest (CA) to hospital discharge from around $5.0 \%$ in 2000, to $10.8 \%$ in 2016.[1-3] However, among the patients surviving to hospital admission, more than half die during admission,[3] and those who survive frequently suffer long term adverse complications, such as myocardial and brain injuries, which impose a significant burden on healthcare systems and society.[3-6]

Cardiac arrest with ROSC entails a complex combination of global ischemic and reperfusion injuries complicated by post recovery myocardial dysfunction that could potentially lead to multi-organ failure.[7-9] Mechanisms that have been put forward as possible explanations for post CA brain injury include free radical formation, excitotoxicity, pathological activation of proteases, and cell death signaling (See Figure 1).[10,11] Many of these injurious processes occur hours to days following ROSC, eventually causing disruption of the blood-brain barrier, neuroinflammation, and delayed neurodegeneration.[12]

A variety of interventions have been proposed to improve the outcome of patients after ROSC. However to-date, the only intervention proven clinically effective is targeted temperature management (TTM).[13] Recently, administration of inhaled gases (e.g. nitric oxide, hydrogen) and in particular noble gases (i.e. Xenon, Argon and Helium) has begun to be explored as a means of decreasing post CA damage. [14]

"Noble" gases, thus nicknamed due to their low reactivity with other elements, are a group of gaseous elements with specific chemical characteristics.[15] Some of these gases are capable of interacting with amino acids in the active sites of several enzymes and receptors, thereby eliciting biological effects.[14] Inhaled noble and other gases are currently being studied in different times in relation to the arrest and in different modes of administration, with and without concurent treatment with TTM. Here we present the results of a systematic review of the literature focusing on the therapeutic use of several inhaled gases after ROSC.

\section{METHODS:}

The study protocol was registered in the International Prospective Register of Systematic Reviews (PROSPERO, CRD42019127179). The study complied with the guidelines of Preferred Reporting Items for Systematic Reviews and Meta-analyses (PRISMA).[16]

Type of studies, participants, interventions and outcomes:

We sought all publications on therapeutic administration of Xenon, Argon, Helium, Nitric oxide, Carbon monoxide, Hydrogen, and Hydrogen Sulfide after cardiopulmonary resuscitation and ROSC. We included both animal and human studies regardless of subject age. We restricted the search to the English language and the search dates to 1960-2019. Due to the scarcity of 
literature on this topic we applied no restrictions to the type of publications, or the outcomes described.

Search methods for identification of studies:

The database searches were conducted several times, last one in March 2020. We searched the Cochrane Central Register of Controlled Trials (CENTRAL) in the Cochrane Library (2016, Issue 3) and MEDLINE, Ovids. We also sought online published abstracts from conference proceedings using the same terms. For trials not yet completed, we searched the clinical trial registry clinicaltrials.gov. Finally, we screened the reference lists of relevant papers (regardless of type) to identify additional papers of relevance. We did not contact authors of previous papers to determine whether additional data were available for inclusion in this review. The detailed search strategy is described in supplementary table 1.

Selection of studies and extraction of information:

The titles and abstracts of all studies were screened by two of the authors (JV and AA) for the following exclusion criteria: (1) Models of local rather than global ischemia (e.g. Infarction, stroke, or surgery). (2) Non-inhalational mode of administration (e.g. intravenous, intraperitoneal). (3) Gas administration before/during CPR (as this is not feasible in real life). (4) Extracorporeal life support. (5) Cardiac arrest induced by hypothermia (Hypothermic CA).

The studies selected by each author were tabulated in an excel file and the files were merged at the end of the process. There was consensus regarding study inclusion as very few papers that met inclusion criteria. Two of the authors ( $A A$ and $S E$ ) extracted the information from the remaining studies, all of which are included in this review. Due to the paucity of human trials and their heterogeneity we performed neither risk of bias assessment nor data metanalysis.

Results:

The search yielded overall 278 publications and 3 registered trials. Figure 2 presents the QUORUM inclusion/exclusion flowchart. Screening of publication titles and abstracts decreased the number of relevant papers to thirty. Full review of the papers further decreased the number of relevant publications to 24 . Screening of references identified an additional 3 articles relevant to the topic of this review, yielding overall 27 articles to be included (See supplementary table 2 for a summary of these articles).

XENON:

Xenon is a naturally occurring very rare element of atmospheric air.[17] It can be manufactured by the fractional distillation of liquefied air; however, this process is very expensive and limited to 9-12 million L/year.[18,19] Therefore, a closed ventilation system is required to efficiently deliver Xe to patients.[19] Xe was first used in humans as an anesthetic agent in 1951, and its safety profile in anesthesia is well established.[20,21] The European Medicines Agency (EMEA) has approved Xe for anesthesia of adults with American Society of Anesthesiology classification 
(ASA) $\leq$ III.[22] As an anesthetic, Xe has several hemodynamic advantages, [23] and in many ways, closely resembles the hypothetical "ideal anesthetic agent".[24] Furthermore, Xe has shown neuroprotective features, potentially through interaction with N-methyl-D-aspartic acid (NMDA), TWIK-related K channel (TREK-1) and adenosine triphosphate-sensitive potassium channel (KATP).[25-27]

Animal models: Experiments on animal models of the post cardiac arrest syndrome have shown that inhalation of $70 \%$ Xe confers neuroprotective features, in terms of neuronal necrosis, neuroinflammation, and functional neurological outcomes as assessed by Neuronal Scale Deficit (NDS), with or without concurrent TTM. [28-30] Xe elicited these protective features when inhalation started 1 hour after ROSC, while early inhalation of Xe (within 10 minutes) showed no such improvement.[29,31] A possible explanation for this apparent conflict lies in the length of time the animals were exposed to high oxygen concentration. In the delayed administration experiments, animals were exposed to $100 \%$ FiO2 for 1 hour before reduction to $30 \%$ and initiation of $\mathrm{Xe}$ inhalation, while early administration experiments started animals on xenon and $30 \% \mathrm{FiO} 2$ immediately after randomization. Prolonged administration of high oxygen concentrations after ROSC is not necessarily beneficial, or even harmful. [32-34] It may therefore be hypothesized that the condition of the animals in delayed administration model may have been worse than the condition of the early treatment group a-priori.

Human subjects: We identified two randomized clinical trials that utilized 40-50\% Xe.[35,36] The first study, by Latitio et al. in 2 multipurpose ICUs in Finland, was a phase II randomized trial (Xe-hypotheca; NCT00879892) showed than Xenon inhalation was safe, convenient, and significantly decreased white matter attenuation.[37-39] However, no statistically significant difference was observed in functional neurological outcomes, as assessed by the Cerebral Performance Category (CPC) score and the modified Rankin Scale (mRS), or mortality rate, at 6months after CA. Nevertheless, these were all secondary end points which the study was not powered to assess. [40]

In addition, a post-hoc analysis of the data showed a decrease of troponin-T release by $44.8 \%$ from the hospital admission to 72 hours after out of hospital cardiac arrest (OHCA) in the $\mathrm{Xe}+$ TTM group, compared to non-significant $11 \%$ decline in the TTM only group.[39] This decrease in troponin-T release could be clinically meaningful given that troponin-T release was independently associated with both short and long term morbidity and mortality in post cardiac arrest patients in several studies.[41,42]

The second clinical study (XePOHCAS; NCT03176186) is an ongoing phase III randomized multicenter clinical trial that has been initiated in 2017 in Denmark and United State.[36] ARGON:

Argon (Ar) has several advantages over Xe. It is easily obtained from air as a by-product of the process of oxygen and nitrogen production.[15] In fact, it is third most abundant gas in the atmosphere.[43] Consequently, Ar can be delivered by inexpensive open-circuit ventilation 
systems. Another advantage for Ar is that it lacks hypnotic and anesthetic features and therefore does not alter patient neurological status.[44]

Several mechanisms of action, such as inhibition of toll-like receptor 2 (TLR2) and toll-like receptor 4 (TLR4) signaling, may explain the possible neuroprotective effects of Ar.[10] While receptors potentially implicated in the neuroprotective effects of xenon, such as NMDA, TREK1 , and KATP, have not been found to interact with Argon (Ar) under normobaric pressure.[10,45]

Animal models: A series of animal studies have evaluated whether Ar confers neuroprotection or cardioprotection, utilizing different concentrations (40\%, 50\%, and 70\%).[44-48] Animals treated with inhaled Ar from 1 hour post-ROSC showed dose-dependent improvement in NDS, dose-independent increased mobility in the open field test, significantly longer activity in the custom-made box test (where rats move along the walls of a brightly illuminated custom-made box, reflecting willingness to explore a previously unknown enviroment), and dose-independent reduction in neurite density index (NDI) in neocortex and hippocampus CA3/4, but not in stratum granulosum, basal ganglia or hippocampus CA1 sector. $[45,49]$ Even better NDS scores and open field test performance as well as a significant reduction in NDI of basal ganglia were shown when treatment with Ar was for 3 hours rather than 1 hour post ROSC.[46] One study has suggested that combining Ar and TTM may abolish the neuroprotective features of TTM.[47] However temperature may have been an effect modifier in this experiment. Animals in the Ar+TTM group had a significantly steeper rise in body temperatures post-extubation compared to those in the TTM only group, reaching temperatures above $37.3{ }^{\circ} \mathrm{C}$ about $6 \mathrm{~h}$ earlier. This finding does however raise questions as additional studies have found that $\mathrm{Ar}$ does not reduce the NDI in hippocampus CA1,[48] which is the brain area most vulnerable to hypoxia. [50]

Ar also does not seem to modify post- ROSC cardiac damage in animal models of CPR as evidenced by the lack of difference in myocardial infarct size, heart rate, or high sensitivity troponin-T level in Ar treated animals [44].

Human studies: No human studies were identified.

HELIUM:

Helium is a colorless, odorless, tasteless, non-toxic, inert, monatomic gas.[51] It is considered relatively cheap (only 5 times the price of oxygen).[52] The mixture of He and oxygen (Heliox) is FDA approved for human administration provided the medical grade of the gas administered is upheld [53], and has been shown to be safe for humans. [54] It has a low density that facilitates transition of small airway gas flow from turbulent to laminar. [55]Therefore, heliox at a He/O2 ratio of 80:20 or 70:30 is used in clinical practice for decreasing the work of breathing during airway obstruction, particularly in upper airway disease.[56] 
Animal studies: As noted above, inhalation of $50 \%$ He did not protect the CA1 sector of the rat hippocampus from damage.[48]

Human studies: Brevoord et al conducted an open label single arm interventional study to assess the safety and feasibility of inhaling heliox 50:50 in adult patients after ROSC.[57] They found no adverse effects attributed to He inhalation, but its neurological and myocardial effects couldn't be assessed, due to the lack of a control group or any other clinical study to use as a comparator.[57]

\section{NITRIC OXIDE:}

Nitric oxide (NO) is a colorless gas formed by the oxidation of nitrogen. [58] It is generated de novo by NO synthases (NOS) through the conversion of L-arginine to NO and L-citrulline.[59] The effects of NO after CA have been studied in models with disrupted de novo synthesis of NO, as well as in models of inhaled NO after CA. Only the latter group meet the inclusion criteria of this paper.

Inhaled NO has been extensively used in a myriad of non-CPR clinical conditions,[60-62] with an excellent safety record.[63]

Animal models: Inhalation of 20 ppm of NO for 6 hours after ROSC, combined with TTM, has been shown to markedly improve the NDS score in a rat model, though no improvement in neurohistological damage was noted.[64] However, prolonged inhalation of 40-60 ppm NO for up to 24 hours post ROSC in a mice model significantly improved 10-day survival rates, prevented brain edema (as assessed by weight diffusion MRI), and improved both neurological and myocardial function. $[65,66]$ The difference in results between the two models can be attributed, in addition to the differences in the model itself, to the study protocols (e.g. the dose of inhaled NO, the time inhalation was initiated and its duration, and the time TTM was initiated).

Human studies: We identified a phase-2, double blinded, randomized clinical trial in the United States (NCT03079102) aims to compare inhalation of NO (carried by nitrogen) to placebo, and will primarily assess death and significant neurological or cardiac outcomes during hospital stay +/- 3 days.[67]

\section{CARBON MONOXIDE:}

CO has historically been known as a toxic gas that, when inhaled, causes significant tissue hypoxia.[68] It does so by displacing oxygen from hemoglobin ( $\mathrm{Hb})$, thus decreasing the blood's oxygen carrying capacity, as well as by inhibiting the electron transport chain in the mitochondria. [68] Nevertheless, inhalation of low doses of $\mathrm{CO}$ is usually tolerated by normal individuals without adverse effects.[69]

Surprisingly, CO has recently emerged to be an endogenous transmitter in humans that plays a role in several physiological processes in different tissues, including neuronal tissues. $[70,71]$ In 
addition, exogenous $\mathrm{CO}$ has also been found to elicit neuroprotective features in several preclinical studies involving cell cultures, mice, and piglets.[72-75] These studies suggest that perhaps $\mathrm{CO}$ should be investigated post-ROSC, despite its potential lethality.

The major challenge with administration of inhaled CO is the accuracy of delivery to ensure administrating potentially therapeutic levels without deleterious effects, especially with prolonged exposures.[76,77] Therefore, other modes of administration have been developed, such as using chemical carriers of this gas, which may be administered intravenously.[77]

Studies: No human or animal studies were identified.

\section{HYDROGEN:}

Hydrogen $(\mathrm{H} 2)$ is the first chemical element in the periodic table. In 2007, it was discovered that hydrogen can reduce the hydroxyl radical (the most cytotoxic of reactive oxygen species), thus eliciting anti-oxidant effects.[78] Administration of $\mathrm{H} 2$ using bottled hydrogen gas mixture is limited to a concentration of $2.9 \%$ due to safety concerns. However, newer devices are now available that can safely deliver up to $67 \%$ of pure hydrogen gas by utilizing water electrolysis.[79]

Animal models: Inhalation of $2 \%$ hydrogen post-ROSC, with or without concurrent TTM, improved survival rates, functional neurological outcomes (NDS scores, motor activity, and spatial memory) and significantly attenuated neuronal damage, including the CA1 sector of the hippocampus in rat models. Moreover, this treatment improved several cardiac parameters such as cardiac work (CW), and left ventricular ejection fraction (LVEF) and decreased the release of cardiac troponin-T.[80,81]

Human studies: Two human studies were identified. The first was single-arm open-label pilot study that showed that post-ROSC inhalation of $2 \% \mathrm{H} 2$ combined with TTM for 18 hours is both feasible and safe.[82] The second study is a randomized, phase II, double-blinded, placebocontrolled trial which is being held in multiple centers in Japan (UMIN ID 000019820). This study intends to assess primarily the 90-day neurological outcome (defined as CPC 1 or 2 ) after inhalation of $2 \% \mathrm{H} 2$ with concurrent TTM. Survival time, 90-day survival rate, GCS score, and the Mini Mental State Examination will be secondary end points.[83]

\section{HYDROGEN SULFIDE:}

Hydrogen sulfide $(\mathrm{H} 2 \mathrm{~S})$ is a colorless and hazardous gas with the odor of "rotten eggs". [84] It occurs naturally in crude petroleum and natural gas industries. [85] H2S is also an endogenous transmitter with several physiologic roles.[86]

Animal studies: Studies have suggested that inhaling H2S post CA may have several beneficial effects, including a higher survival rate, better functional neurological outcome (NDS and tape removal test), smaller rise in plasma S100B levels, more preserved neuronal density and cell morphology of hippocampus CA1 sector, enhanced metabolism (increased cerebral extraction 
of $\mathrm{O} 2$, reduced glucose consumption, and faster lactate clearance, suggesting earlier transition from anaerobic glycolysis to oxidative phosphorylation), as well as maintenance of the structural integrity of the blood brain barrier, leading to decreased brain edema.[87-90]

Human studies: No human studies were identified.

CONCLUSION:

A variety of noble and other gases are readily available for therapeutic use. Although, postROSC inhalation of these gases remains a relatively unstudied field of research, several animal and some human studies have shown more than just a theoretical potential to elicit neuroprotective effects in patients after cardiac arrest. Larger scale clinical trials are needed to further explore these agents.

FUNDING: The author(s) received no specific funding for this work.

\section{REFERENCES:}

[1] Ocegueda-Pacheco C, Varon J: ECPR: Are we ready for primetime? Resuscitation 2016; 103:A6-A7

[2] Savastano S, Klersy C, Raimondi M, et al.: Positive trend in survival to hospital discharge after out-of-hospital cardiac arrest: a quantitative review of the literature. J Cardiovasc Med (Hagerstown) 2014; 15:609-15

[3] Benjamin EJ, Virani SS, Callaway CW, et al.: Heart Disease and Stroke Statistics-2018 Update: A Report From the American Heart Association. Circulation 2018; 137:e67-e492

[4] Kim Y-J, Ahn S, Sohn CH, et al.: Long-term neurological outcomes in patients after outof-hospital cardiac arrest. Resuscitation 2016; 101:1-5

[5] Elmer J, Rittenberger JC, Coppler PJ, et al.: Long-term survival benefit from treatment at a specialty center after cardiac arrest. Resuscitation 2016; 108:48-53

[6] Ginsberg GM, Kark JD, Einav S: Cost-utility analysis of treating out of hospital cardiac arrests in Jerusalem. Resuscitation 2015; 86:54-61

[7] Winther-Jensen M, Kjaergaard J, Lassen JF, et al.: Use of renal replacement therapy after out-of-hospital cardiac arrest in Denmark 2005-2013. Scand Cardiovasc J 2018; 52:238-243

[8] Laver S, Farrow C, Turner D, et al.: Mode of death after admission to an intensive care unit following cardiac arrest. Intensive Care Med 2004; 30:2126-8

[9] Riddersholm S, Kragholm K, Mortensen RN, et al.: Organ support therapy in the intensive care unit and return to work in out-of-hospital cardiac arrest survivors-A nationwide cohort study. Resuscitation 2018; 125:126-134 
[10] Ulbrich F, Goebel U: The Molecular Pathway of Argon-Mediated Neuroprotection. Int J Mol Sci 2016; 17:1816

[11] Uchino $\mathrm{H}$, Ogihara $\mathrm{Y}$, Fukui $\mathrm{H}$, et al.: Brain injury following cardiac arrest: pathophysiology for neurocritical care. J intensive care 2016; 4:31

[12] Ichinose F: Improving outcomes after cardiac arrest using NO inhalation. Trends Cardiovasc Med 2013; 23:52-8

[13] Polderman KH, Varon J: How low should we go? Hypothermia or strict normothermia after cardiac arrest? Circulation 2015; 131:669-75

[14] Jawad N, Rizvi M, Gu J, et al.: Neuroprotection (and lack of neuroprotection) afforded by a series of noble gases in an in vitro model of neuronal injury. Neurosci Lett 2009; 460:232-6

[15] Ozima M, Podosek FA: Noble Gas Geochemistry. 2nd ed. Cambridge: Cambridge University Press; 2001.

16. Moher D, Liberati A, Tetzlaff J, et al.: Preferred reporting items for systematic reviews and meta-analyses: the PRISMA statement. PLoS Med 2009; 6:e1000097

[17] Joyce JA: Xenon: anesthesia for the 21st century. AANA J 2000; 68:259-64

[18] Aziz TS: Xenon in anesthesia. Int Anesthesiol Clin 2001; 39:1-14

[19] Chakkarapani E, Thoresen M, Hobbs CE, et al.: A closed-circuit neonatal xenon delivery system: a technical and practical neuroprotection feasibility study in newborn pigs. Anesth Analg 2009; 109:451-60

[20] CULLEN SC, GROSS EG: The anesthetic properties of xenon in animals and human beings, with additional observations on krypton. Science 1951; 113:580-2

[21] Jordan BD, Wright EL: Xenon as an anesthetic agent. AANA J 2010; 78:387-92

[22] Derwall M, Coburn M, Rex S, et al.: Xenon: recent developments and future perspectives. Minerva Anestesiol 2009; 75:37-45

[23] Neukirchen M, Schaefer MS, Kern C, et al.: Xenon does not increase heart rate-corrected cardiac QT interval in volunteers and in patients free of cardiovascular disease. Anesthesiology $2015 ; 123: 542-7$

[24] Preckel B, Schlack W: Inert gases as the future inhalational anaesthetics? Best Pract Res Clin Anaesthesiol 2005; 19:365-79

[25] Gruss M, Bushell TJ, Bright DP, et al.: Two-pore-domain K+ channels are a novel target for the anesthetic gases xenon, nitrous oxide, and cyclopropane. Mol Pharmacol 2004; 65:44352 
[26] Dickinson R, Peterson BK, Banks P, et al.: Competitive inhibition at the glycine site of the $\mathrm{N}$-methyl-D-aspartate receptor by the anesthetics xenon and isoflurane: evidence from molecular modeling and electrophysiology. Anesthesiology 2007; 107:756-67

[27] Bantel C, Maze M, Trapp S: Noble gas xenon is a novel adenosine triphosphate-sensitive potassium channel opener. Anesthesiology 2010; 112:623-30

[28] Fries $\mathrm{M}$, Nolte KW, Coburn M, et al.: Xenon reduces neurohistopathological damage and improves the early neurological deficit after cardiac arrest in pigs. Crit Care Med 2008;

36:2420-6

[29] Derwall M, Timper A, Kottmann K, et al.: Neuroprotective effects of the inhalational anesthetics isoflurane and xenon after cardiac arrest in pigs. Crit Care Med 2008; 36:S492-5

[30] Fries M, Brücken A, Çizen A, et al.: Combining xenon and mild therapeutic hypothermia preserves neurological function after prolonged cardiac arrest in pigs. Crit Care Med 2012; 40:1297-303

[31] Fries M, Coburn M, Nolte KW, et al.: Early administration of xenon or isoflurane may not improve functional outcome and cerebral alterations in a porcine model of cardiac arrest. Resuscitation 2009; 80:584-90

[32] Nelskylä A, Nurmi J, Jousi M, et al.: The effect of $50 \%$ compared to $100 \%$ inspired oxygen fraction on brain oxygenation and post cardiac arrest mitochondrial function in experimental cardiac arrest. Resuscitation 2017; 116:1-7

[33] Brücken A, Kaab AB, Kottmann K, et al.: Reducing the duration of $100 \%$ oxygen ventilation in the early reperfusion period after cardiopulmonary resuscitation decreases striatal brain damage. Resuscitation 2010; 81:1698-703

[34] Balan IS, Fiskum G, Hazelton J, et al.: Oximetry-guided reoxygenation improves neurological outcome after experimental cardiac arrest. Stroke 2006; 37:3008-13

[35] Nachnani JS, Bulchandani D, Moormeier J, et al.: Patient and physician predictors of inappropriate acid-suppressive therapy (AST) use in hospitalized patients. J Hosp Med 2009; 4:E10-4

[36] ClinicalTrials.gov [Internet]. NeuroproteXeon (Inc): National Library of Medicine (US). 2000 Feb 29. Identifier NCT03176186, Xenon for Neuroprotection During Post-Cardiac Arrest Syndrome in Comatose Survivors of an Out of Hospital Cardiac Arrest (XePOHCAS); 2017 June 5; Available from: https://clinicaltrials.gov/ct2/show/study/NCT03176186

[37] ClinicalTrials.gov [Internet]. Laitio (MD): National Library of Medicine (US). 2000 Feb 29. Identifier NCT00879892, Effect of Xenon and Therapeutic Hypothermia, on the Brain and on Neurological Outcome Following Brain Ischemia in Cardiac Arrest Patients (Xe-hypotheca); 2009 April 13; Available from: https://clinicaltrials.gov/ct2/show/study/NCT00879892 
[38] Arola OJ, Laitio RM, Roine RO, et al.: Feasibility and cardiac safety of inhaled xenon in combination with therapeutic hypothermia following out-of-hospital cardiac arrest. Crit Care Med 2013; 41:2116-24

[39] Arola O, Saraste A, Laitio R, et al.: Inhaled Xenon Attenuates Myocardial Damage in Comatose Survivors of Out-of-Hospital Cardiac Arrest: The Xe-Hypotheca Trial. J Am Coll Cardiol 2017; 70:2652-2660

[40] Laitio R, Hynninen M, Arola O, et al.: Effect of Inhaled Xenon on Cerebral White Matter Damage in Comatose Survivors of Out-of-Hospital Cardiac Arrest: A Randomized Clinical Trial. JAMA 2016; 315:1120-8

[41] Babuin L, Vasile VC, Rio Perez JA, et al.: Elevated cardiac troponin is an independent risk factor for short- and long-term mortality in medical intensive care unit patients. Crit Care Med 2008; 36:759-65

[42] Gilje P, Koul S, Thomsen JH, et al.: High-sensitivity troponin-T as a prognostic marker after out-of-hospital cardiac arrest - A targeted temperature management (TTM) trial substudy. Resuscitation 2016; 107:156-61

[43] Auwärter V, Pragst F, Strauch H: Analytical investigations in a death case by suffocation in an argon atmosphere. Forensic Sci Int 2004; 143:169-75

[44] Ristagno G, Fumagalli F, Russo I, et al.: Postresuscitation treatment with argon improves early neurological recovery in a porcine model of cardiac arrest. Shock $2014 ; 41: 72-8$

[45] Brücken A, Kurnaz P, Bleilevens C, et al.: Dose dependent neuroprotection of the noble gas argon after cardiac arrest in rats is not mediated by K(ATP)-channel opening. Resuscitation 2014; 85:826-32

[46] Brücken A, Kurnaz P, Bleilevens C, et al.: Delayed argon administration provides robust protection against cardiac arrest-induced neurological damage. Neurocrit Care 2015; 22:112-20

[47] Brücken A, Bleilevens C, Föhr P, et al.: Influence of argon on temperature modulation and neurological outcome in hypothermia treated rats following cardiac arrest. Resuscitation 2017; 117:32-39

[48] Zuercher P, Springe D, Grandgirard D, et al.: A randomized trial of the effects of the noble gases helium and argon on neuroprotection in a rodent cardiac arrest model. BMC Neurol 2016; 16:43

[49] Brücken A, Cizen A, Fera C, et al.: Argon reduces neurohistopathological damage and preserves functional recovery after cardiac arrest in rats. Br J Anaesth 2013; 110 Suppl:i106-12 
[50] Bartsch T, Döhring J, Reuter S, et al.: Selective neuronal vulnerability of human hippocampal CA1 neurons: lesion evolution, temporal course, and pattern of hippocampal damage in diffusion-weighted MR imaging. J Cereb Blood Flow Metab 2015; 35:1836-45

[51] Chemistry of the Elements. Second Edi. Oxford: Elsevier; 1997.

[52] Jurickova I, Roubík K, Muller M: Delivery of heliox with a semi-closed circuit during spontaneous breathing: a comparative economic theoretical study. BMC Pulm Med 2015; 15:65

[53] FDA: Food and Drug Administration Drug approval [Online] [Internet]. [cited 2020 Feb 5] Available from:

https://www.accessdata.fda.gov/scripts/cder/daf/index.cfm?event=overview.process\&ApplNo $=205819$

[54] Allan PF, Thomas K V, Ward MR, et al.: Feasibility study of noninvasive ventilation with helium-oxygen gas flow for chronic obstructive pulmonary disease during exercise. Respir Care 2009; 54:1175-82

[55] Hess DR, Fink JB, Venkataraman ST, et al.: The history and physics of heliox. Respir Care 2006; 51:608-12

[56] Levy SD, Alladina JW, Hibbert KA, et al.: High-flow oxygen therapy and other inhaled therapies in intensive care units. Lancet (London, England) 2016; 387:1867-78

[57] Brevoord D, Beurskens CJP, van den Bergh WM, et al.: Helium ventilation for treatment of post-cardiac arrest syndrome: A safety and feasibility study. Resuscitation 2016; 107:145-9

[58] Tsukahara H, Ishida T, Mayumi M: Gas-phase oxidation of nitric oxide: chemical kinetics and rate constant. Nitric oxide Biol Chem 1999; 3:191-8

[59] Adams JA, Wu D, Bassuk J, et al.: Nitric oxide synthase isoform inhibition before whole body ischemia reperfusion in pigs: vital or protective? Resuscitation 2007; 74:516-25

[60] Ventetuolo CE, Klinger JR: Management of acute right ventricular failure in the intensive care unit. Ann Am Thorac Soc 2014; 11:811-22

[61] Akmal $\mathrm{AH}$, Hasan $\mathrm{M}$ : Role of nitric oxide in management of acute respiratory distress syndrome. Ann Thorac Med 2008; 3:100-3

[62] Derwall M, Ebeling A, Nolte KW, et al.: Inhaled nitric oxide improves transpulmonary blood flow and clinical outcomes after prolonged cardiac arrest: a large animal study. Crit Care 2015; $19: 328$

[63] Monsalve-Naharro JÁ, Domingo-Chiva E, García Castillo S, et al.: Inhaled nitric oxide in adult patients with acute respiratory distress syndrome. Farm Hosp 2017; 41:292-312 
[64] Brücken A, Bleilevens C, Berger $P$, et al.: Effects of inhaled nitric oxide on outcome after prolonged cardiac arrest in mild therapeutic hypothermia treated rats. Sci Rep 2018; 8:6743

[65] Minamishima S, Kida K, Tokuda K, et al.: Inhaled nitric oxide improves outcomes after successful cardiopulmonary resuscitation in mice. Circulation 2011; 124:1645-53

[66] Kida K, Shirozu K, Yu B, et al.: Beneficial effects of nitric oxide on outcomes after cardiac arrest and cardiopulmonary resuscitation in hypothermia-treated mice. Anesthesiology 2014; 120:880-9

[67] ClinicalTrials.gov [Internet]. Cameron Dezfulian: National Library of Medicine (US). 2000 Feb 29. Identifier NCT03079102, Inhaled Nitric Oxide After Out-of-Hospital Cardiac Arrest (iNOOHCA); 2017 March 14 [cited 2018 Dec 8]; Available from: https://clinicaltrials.gov/ct2/show/study/NCT03079102

[68] Reumuth G, Alharbi Z, Houschyar KS, et al.: Carbon monoxide intoxication: What we know. Burns 2019; 45:526-530

[69] Allred EN, Bleecker ER, Chaitman BR, et al.: Effects of carbon monoxide on myocardial ischemia. Environ Health Perspect 1991; 91:89-132

[70] Hanafy KA, Oh J, Otterbein LE: Carbon Monoxide and the brain: time to rethink the dogma. Curr Pharm Des 2013; 19:2771-5

[71] Mahan VL: Neuroprotective, neurotherapeutic, and neurometabolic effects of carbon monoxide. Med Gas Res 2012; 2:32

[72] Vieira HLA, Queiroga CSF, Alves PM: Pre-conditioning induced by carbon monoxide provides neuronal protection against apoptosis. J Neurochem 2008; 107:375-84

[73] Zeynalov E, Doré S: Low doses of carbon monoxide protect against experimental focal brain ischemia. Neurotox Res 2009; 15:133-7

[74] Wang B, Cao W, Biswal S, et al.: Carbon monoxide-activated Nrf2 pathway leads to protection against permanent focal cerebral ischemia. Stroke 2011; 42:2605-10

[75] Almeida AS, Queiroga CSF, Sousa MFQ, et al.: Carbon monoxide modulates apoptosis by reinforcing oxidative metabolism in astrocytes: role of Bcl-2. J Biol Chem 2012; 287:10761-70

[76] El-Mousleh T, Casalis PA, Wollenberg I, et al.: Exploring the potential of low doses carbon monoxide as therapy in pregnancy complications. Med Gas Res 2012; 2:4

[77] Motterlini R, Mann BE, Foresti R: Therapeutic applications of carbon monoxide-releasing molecules. Expert Opin Investig Drugs 2005; 14:1305-18

[78] Ohsawa I, Ishikawa M, Takahashi K, et al.: Hydrogen acts as a therapeutic antioxidant by selectively reducing cytotoxic oxygen radicals. Nat Med 2007; 13:688-94 
[79] Camara R, Huang L, Zhang JH: The production of high dose hydrogen gas by the AMS-H01 for treatment of disease. Med Gas Res 2016; 6:164-166

[80] Hayashida K, Sano M, Kamimura N, et al.: Hydrogen inhalation during normoxic resuscitation improves neurological outcome in a rat model of cardiac arrest independently of targeted temperature management. Circulation 2014; 130:2173-80

[81] Wang P, Jia L, Chen B, et al.: Hydrogen Inhalation is Superior to Mild Hypothermia in Improving Cardiac Function and Neurological Outcome in an Asphyxial Cardiac Arrest Model of Rats. Shock 2016; 46:312-8

[82] Tamura T, Hayashida K, Sano M, et al.: Feasibility and Safety of Hydrogen Gas Inhalation for Post-Cardiac Arrest Syndrome - First-in-Human Pilot Study -. Circ J 2016; 80:1870-1873

[83] Tamura T, Hayashida K, Sano M, et al.: Efficacy of inhaled HYdrogen on neurological outcome following BRain Ischemia During post-cardiac arrest care (HYBRID II trial): study protocol for a randomized controlled trial. Trials $2017 ; 18: 488$

[84] Wang R: Hydrogen sulfide: the third gasotransmitter in biology and medicine. Antioxid Redox Signal 2010; 12:1061-4

[85] Luo L, Liu Y-J, Wang X-C: [Distribution and diversity of sulfate-reducing bacteria in a crude oil gathering and transferring system]. Huan jing ke xue= Huanjing kexue 2010; 31:21605

[86] Gadalla MM, Snyder SH: Hydrogen sulfide as a gasotransmitter. J Neurochem 2010; 113:14-26

[87] Wei X, Duan L, Bai L, et al.: Effects of exogenous hydrogen sulfide on brain metabolism and early neurological function in rabbits after cardiac arrest. Intensive Care Med 2012; 38:1877-85

[88] Geng Y, Li E, Mu Q, et al.: Hydrogen sulfide inhalation decreases early blood-brain barrier permeability and brain edema induced by cardiac arrest and resuscitation. J Cereb Blood Flow Metab 2015; 35:494-500

[89] Wei X, Zhang B, Zhang Y, et al.: Hydrogen Sulfide Inhalation Improves Neurological Outcome via NF-kB-Mediated Inflammatory Pathway in a Rat Model of Cardiac Arrest and Resuscitation. Cell Physiol Biochem 2015; 36:1527-38

[90] Chen W-L, Niu Y-Y, Jiang W-Z, et al.: Neuroprotective effects of hydrogen sulfide and the underlying signaling pathways. Rev Neurosci 2015; 26:129-42

FIGURE LEGENDS: 
1) Figure 1: Acute excitotoxicity after cardiac arrest.

2) Figure 2: Flow chart of search methods. 


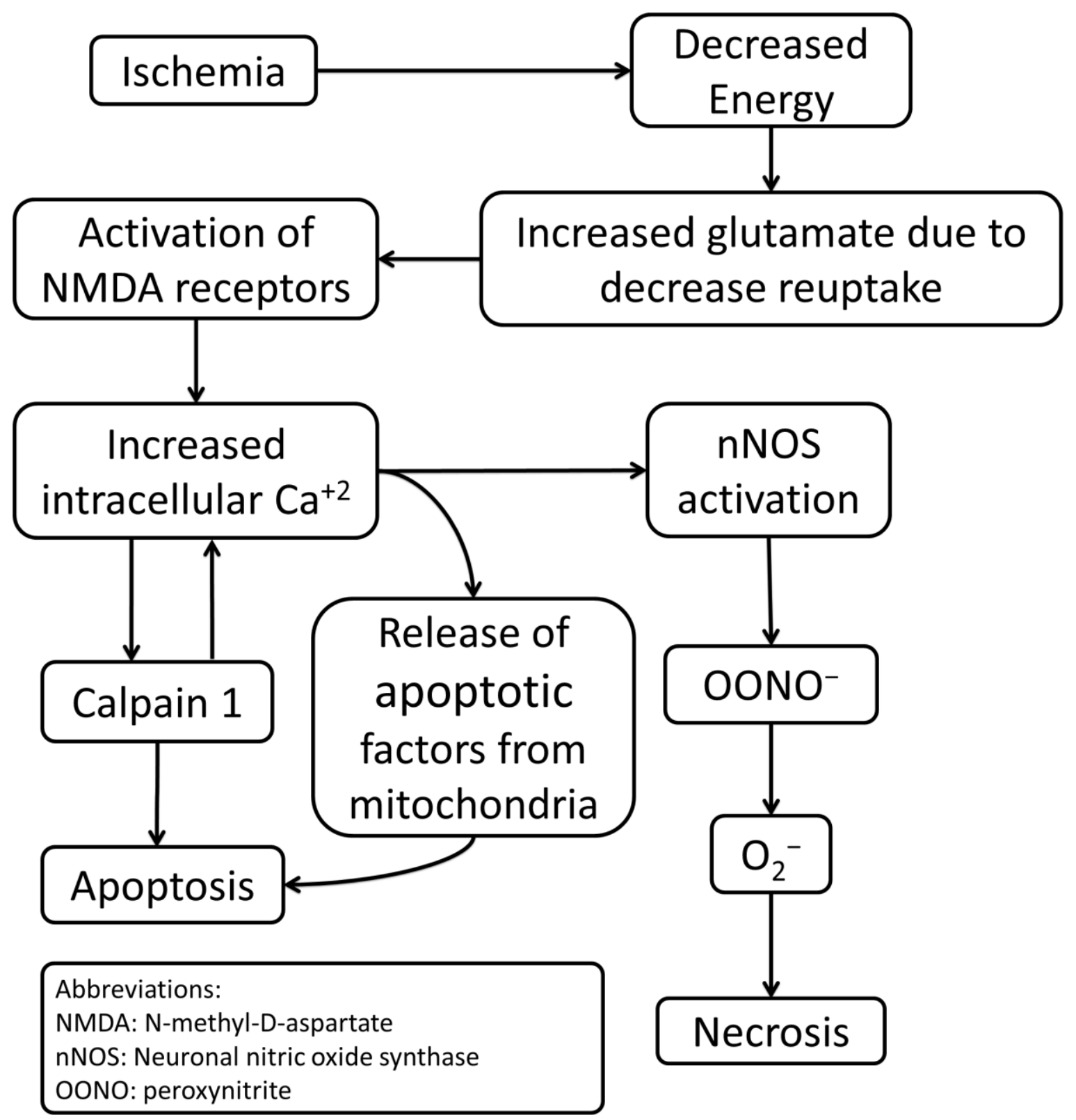




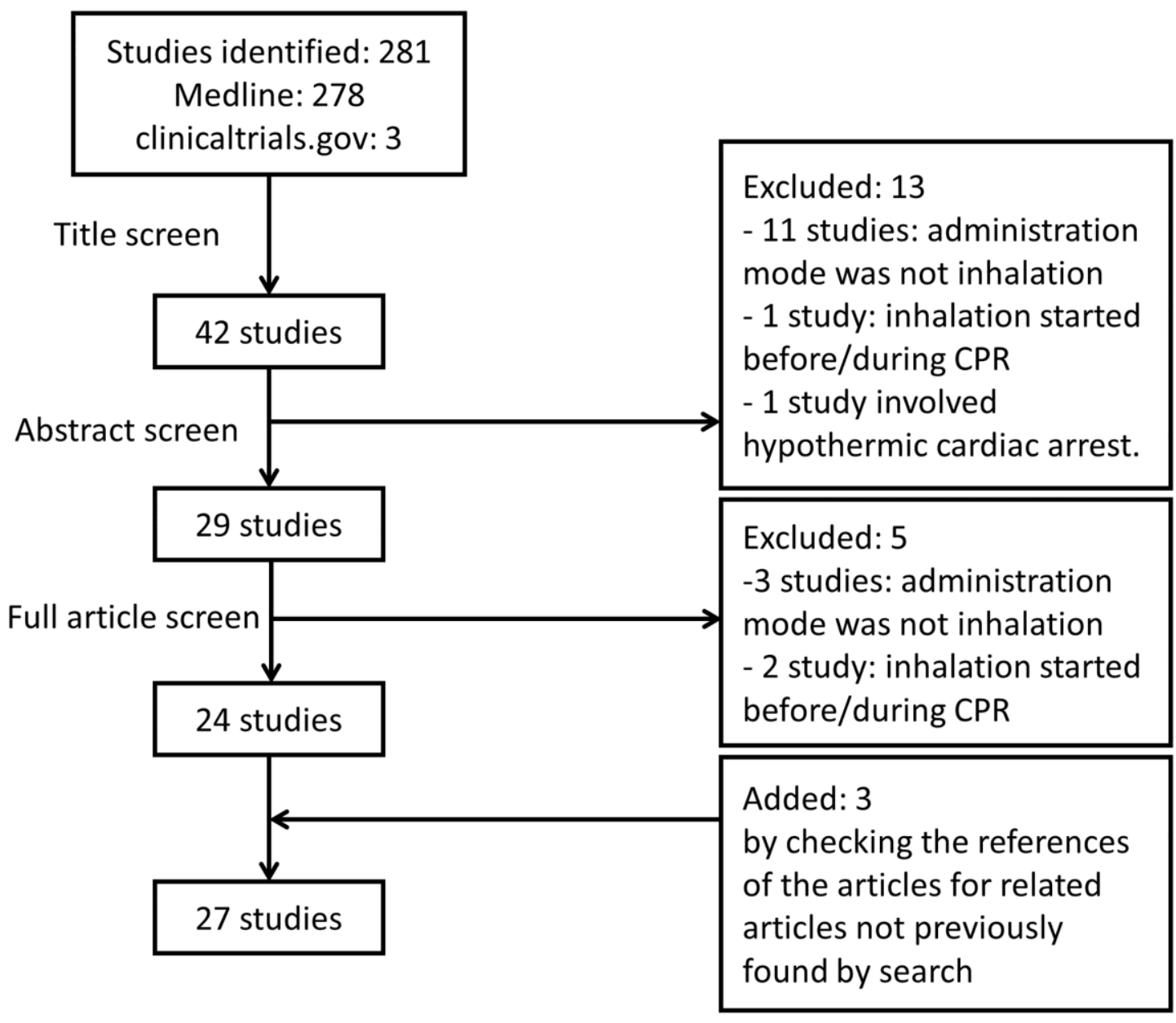


Supplementary table 1: Search Strategy.

\begin{tabular}{|c|c|c|}
\hline $\begin{array}{c}\text { noble gases } \\
\text { OR } \\
\text { argon } \\
\text { OR } \\
\text { Xenon } \\
\text { OR } \\
\text { Helium } \\
\text { OR } \\
\text { "Nitric oxide" } \\
\text { OR } \\
\text { "carbon monoxide" } \\
\text { OR } \\
\text { Hydrogen } \\
\text { OR } \\
\text { hydrogen sulfide }\end{array}$ & $\begin{array}{c}\text { return of spontaneous circulation" } \\
\text { OR } \\
\text { "post cardiac arrest syndrome" } \\
\text { OR } \\
\text { "out of hospital cardiac arrest/therapy" } \\
\text { OR } \\
\text { "heart arrest" } \\
\text { OR } \\
\text { cardiopulmonary resuscitation }\end{array}$ & $\begin{array}{c}\text { Treatment Outcome } \\
\text { OR } \\
\text { Prognosis } \\
\text { OR } \\
\text { Neuroprotection } \\
\text { OR } \\
\text { Cardioprotection } \\
\text { OR } \\
\text { protective agents } \\
\text { OR } \\
\text { Cardioprotective } \\
\text { OR } \\
\text { Neuroprotective } \\
\text { OR } \\
\text { Neuroprotectant } \\
\text { OR } \\
\text { Cardioprotectant } \\
\text { OR } \\
\text { Cardiotonic Agents }\end{array}$ \\
\hline
\end{tabular}




\begin{tabular}{|c|c|c|c|c|c|c|c|c|c|}
\hline \multirow[t]{2}{*}{ Reference } & \multirow[t]{2}{*}{ Gas } & \multirow[t]{2}{*}{ Model } & \multicolumn{2}{|c|}{$\begin{array}{l}\text { Number of } \\
\text { subjects }\end{array}$} & \multicolumn{2}{|c|}{ Inhaled gas composition } & \multirow{2}{*}{$\begin{array}{l}\text { Interval } \\
\text { from ROSC } \\
\text { to onset of } \\
\text { inhalation }\end{array}$} & \multirow{2}{*}{$\begin{array}{l}\text { Duration of } \\
\text { inhalation }\end{array}$} & \multirow[t]{2}{*}{ Outcomes } \\
\hline & & & I & C & I & C & & & \\
\hline Fries 2008[28] & $\mathrm{Xe}$ & $\begin{array}{c}\text { pigs (male, } 3-4 \\
\text { mo) }\end{array}$ & $8 / 9$ & 8 & $\begin{array}{c}70 \% \mathrm{Xe}+ \\
30 \% \mathrm{O} 2\end{array}$ & $\begin{array}{c}70 \% \mathrm{~N} 2+ \\
30 \% \mathrm{O} 2\end{array}$ & $1 \mathrm{hr}$ & $\begin{array}{l}1 \text { or } 5 \text { hrs } \\
\text { for Xe, } 5 \\
\text { hrs for } \\
\text { controls }\end{array}$ & $\begin{array}{l}\text { Significantly reduced scores for necrosis and neuronal } \\
\text { inflammation in the putamen and caudate nucleus on d } 5 \\
\text { post-ROSC; reduced NDS in } 1 \mathrm{~h} \text { group and, to a lesser } \\
\text { extent, in } 5 \mathrm{~h} \text { group, compared to controls on d 1-3 post- } \\
\text { ROSC }\end{array}$ \\
\hline $\begin{array}{l}\text { Derwall } \\
2008[29] / 1^{\text {st }} \\
\text { protocol }\end{array}$ & $\mathrm{Xe}$ & pigs 3-4 mo & $8 / g$ & 8 & $\begin{array}{c}70 \% \mathrm{Xe}+ \\
30 \% \mathrm{O} 2\end{array}$ & $\begin{array}{c}70 \% \mathrm{~N} 2+ \\
30 \% \mathrm{O} 2\end{array}$ & $1 \mathrm{hr}$ & 1 or $5 \mathrm{hrs}$ & $\begin{array}{l}\text { Reduced NDS in } 1 \mathrm{hr} \text { group and, to a lesser extent, in } 5 \mathrm{hrs} \\
\text { group, compared to controls on d } 2,3 \text { post-ROSC; improved } \\
\text { neurocognitive testing on d } 2,3 \text { post-ROSC }\end{array}$ \\
\hline $\begin{array}{l}\text { Derwall } \\
2008[29] / 2^{\text {nd }} \\
\text { protocol }\end{array}$ & $\mathrm{Xe}$ & $\begin{array}{c}\text { pigs (male, } 3-4 \\
\text { mo) }\end{array}$ & 7 & 7 & $\begin{array}{c}70 \% \mathrm{Xe}+ \\
30 \% \mathrm{O} 2\end{array}$ & $\begin{array}{c}70 \% \mathrm{~N} 2+ \\
30 \% \mathrm{O} 2\end{array}$ & $10 \mathrm{~min}$ & $1 \mathrm{hr}$ & $\begin{array}{c}\text { No improvement in neurocognitive testing or NDS on d 1-4 } \\
\text { post-ROSC }\end{array}$ \\
\hline Fries 2009[31] & $\mathrm{Xe}$ & $\begin{array}{c}\text { pigs (male, } 3-4 \\
\text { mo) }\end{array}$ & 7 & 7 & $\begin{array}{l}70 \% \mathrm{Xe}+ \\
30 \% \mathrm{O} 2\end{array}$ & $\begin{array}{c}70 \% \mathrm{~N} 2+ \\
30 \% \mathrm{O} 2\end{array}$ & $10 \mathrm{~min}$ & $1 \mathrm{hr}$ & $\begin{array}{l}\text { No improvement in neurocognitive testing or NDS on d } 1-4 \\
\text { post-ROSC, no reduction in neurohistopathological damage } \\
\text { on d } 5 \text { post-ROSC }\end{array}$ \\
\hline Fries 2012[30] & $\mathrm{Xe}$ & $\begin{array}{c}\text { Pigs (male, } 4 \\
\text { mo) }\end{array}$ & $5 / g$ & 5 & $\begin{array}{l}\text { 1. TTM } \\
\text { 2. TTM + } \\
70 \% \text { Xe }+ \\
30 \% \text { O2 }\end{array}$ & $\begin{array}{c}70 \% \mathrm{~N} 2+ \\
30 \% \mathrm{O} 2\end{array}$ & $1 \mathrm{hr}$ & $\begin{array}{l}\text { TTM } 16 \mathrm{hrs} \\
\text { Xe: } 1 \mathrm{hr}\end{array}$ & $\begin{array}{l}\text { Combined therapy (TTM+XE) was superior to TTM in terms of } \\
\text { functional neurological outcome, neurophysiological damage } \\
\text { and hemodynamic instability }\end{array}$ \\
\hline $\begin{array}{l}\text { Xe-hypotheca[37- } \\
40]\end{array}$ & $\mathrm{Xe}$ & $\begin{array}{l}\text { Adult Humans } \\
18-80 \text { yrs with } \\
\text { rhythmic CA }\end{array}$ & \multicolumn{2}{|c|}{110} & $\begin{array}{l}\mathrm{TTM}+40 \% \\
\quad \mathrm{Xe}\end{array}$ & TTM only & $\begin{array}{l}\text { Immediately } \\
\text { after } \\
\text { randomizati } \\
\text { on }\end{array}$ & $24 \mathrm{hrs}$ & $\begin{array}{c}\text { Xenon use was safe and convenient, and resulted in } \\
\text { attenuated white matter damage (assessed by fractional } \\
\text { anisotropy from tensor MRI at } 36-52 \mathrm{hrs} \text { post CA), lower } \\
\text { troponin-T release at } 72 \mathrm{hrs} \text { post CA }(0.22 \mu \mathrm{g} / \mathrm{l}, 95 \% \mathrm{Cl} 0.05 \\
-0.69 \mu \mathrm{g} / \mathrm{l} \mathrm{vs} 0.40 \mu \mathrm{g} / \mathrm{l}, 95 \% \mathrm{Cl} 0.14-1.87 \mu \mathrm{g} / \mathrm{l}) \text {, and lower } \\
\text { heart rate (median HR during the first } 72 \mathrm{hrs}: 61.6 \text { [56.8-69.4] } \\
\text { vs } 68.8 \text { [59.8-75.9]) }\end{array}$ \\
\hline Xephoca trial[36] & $\mathrm{Xe}$ & $\begin{array}{l}\text { Adult Humans } \\
\text { (18-80 yrs) }\end{array}$ & \multicolumn{2}{|c|}{1436} & $\begin{array}{c}\mathrm{TTM}+50 \% \\
\mathrm{Xe}\end{array}$ & TTM only & & $24 \mathrm{hrs}$ & $\begin{array}{l}\text { This study will assess outcomes not adequately powered by } \\
\text { the (Xe-hypotheca) trial. The study will primarily compare the } \\
\text { functional neurological outcome by comparing the mRS } \\
\text { results at } 30 \text { days after CA. The secondary end point of the } \\
\text { study is to determine the mortality at } 30 \text { days post CA }\end{array}$ \\
\hline Brücken 2013[49] & $\mathrm{Ar}$ & Rats & 7 & 7 & $\begin{array}{l}70 \% \mathrm{Ar}+ \\
30 \% \mathrm{O} 2\end{array}$ & $\begin{array}{c}70 \% \mathrm{~N} 2+ \\
30 \% \mathrm{O} 2\end{array}$ & 1 & 1 & $\begin{array}{l}\text { Ar group had better NDS score throughout all the } 7 \text { days post } \\
\text { CPR, were significantly more mobile in the open field test on } \\
\text { day } 4 \text { after CPR, moved significantly longer along the walls } \\
\text { when placed in a brightly illuminated custom-made box } \\
\text { (reflecting better general locomotor activity and willingness to } \\
\text { explore a previously unknown environment). No difference in } \\
\text { the Morris Watermaze mean speed was noted. Reduction in } \\
\text { NDI was noted in neocortex and hippocampus (except CA1), } \\
\text { but not in stratum granulosum, basal ganglia. }\end{array}$ \\
\hline Brücken 2014[45] & $\mathrm{Ar}$ & Rats & 47 & & $\begin{array}{l}40 \% \mathrm{Ar}+ \\
30 \% \mathrm{O} 2+ \\
30 \% \mathrm{~N} 2 \mathrm{OR} \\
70 \% \mathrm{Ar}+ \\
30 \% \mathrm{O} 2\end{array}$ & No treatment & 1 & 1 & $\begin{array}{l}\text { Dose dependent improvement in NDS. Better mobility in the } \\
\text { open field test for } 70 \% \text { Ar group. Dose independent reduction } \\
\text { in NDI of the neocortex and hippocampal CA } 3 / 4 \text { in Ar treated } \\
\text { animals. }\end{array}$ \\
\hline
\end{tabular}




\begin{tabular}{|c|c|c|c|c|c|c|c|c|c|}
\hline Brücken 2015[46] & $\mathrm{Ar}$ & Rats & \multicolumn{2}{|c|}{24} & $\begin{array}{c}70 \mathrm{Ar}+30 \% \\
\mathrm{O} 2\end{array}$ & $\begin{array}{l}70 \% \mathrm{~N} 2+ \\
30 \% \mathrm{O} 2\end{array}$ & 1 or 3 & 1 & $\begin{array}{c}\text { Delayed Ar group had better NDS, open field test and basal } \\
\text { ganglia NDI }\end{array}$ \\
\hline Brücken 2017[47] & $\mathrm{Ar}$ & Rats & \multicolumn{2}{|c|}{21} & $\begin{array}{l}\text { TTM }+70 \% \\
\text { Ar OR TTM } \\
\text { alone }\end{array}$ & $\begin{array}{l}\text { No treatment } \\
\text { and } \\
\text { normothermic }\end{array}$ & 1 & 1 & $\begin{array}{c}\text { Ar + TTM group had steeper rise in body temperature 2-10 } \\
\text { hrs post-extubation compared to TTM alone group. } \\
\text { Apparently, Ar abolished the protective effects of TTM, and } \\
\text { this was reflected by worse NDS and neurohistopathological } \\
\text { damage in the Ar TTM group. }{ }^{2}\end{array}$ \\
\hline Ristagno 2014[44] & $\mathrm{Ar}$ & Swine & \multicolumn{2}{|c|}{12} & $\begin{array}{l}70 \% \mathrm{Ar}+ \\
30 \% \mathrm{O} 2\end{array}$ & $\begin{array}{l}70 \% \mathrm{~N} 2+ \\
30 \% \mathrm{O} 2\end{array}$ & $5 \mathrm{~min}$ & $4 \mathrm{hrs}$ & $\begin{array}{c}\text { No difference in myocardial infarct size or high sensitivity } \\
\text { troponin-T level was noted. Ar group had higher alertness } \\
\text { scores and lower NDS } 24,72 \text { (but not } 48 \text { ) hrs post-ROSC, and } \\
\text { minimal increase in NSE level from baseline to } 72 \text { hours post- } \\
\text { ROSC ( } 12 \% \text { vs } 234 \%) \text {. No difference in neuronal loss in } \\
\text { hippocampal CA1 sector was noted. }\end{array}$ \\
\hline Zuercher 2016[48] & $\mathrm{Ar}$ & Rats & \multicolumn{2}{|c|}{40} & $\begin{array}{l}50 \% \mathrm{Ar} \mathrm{OR} \\
50 \% \mathrm{He}+ \\
50 \% \mathrm{O} 2\end{array}$ & $\begin{array}{c}50 \% \mathrm{~N} 2+ \\
50 \% \mathrm{O} 2\end{array}$ & 4 & 20 & $\begin{array}{l}\text { Neurohistological examination of the hippocampal CA1 } \\
\text { segment using Fluoro-Jade B staining showed no difference } \\
\text { in neuronal loss between study groups }\end{array}$ \\
\hline Brevoord 2016[57] & $\mathrm{He}$ & $\begin{array}{l}\text { Adult humans } \\
\text { arrived at } \\
\text { hospital within } \\
30 \text { min of CA }\end{array}$ & \multicolumn{2}{|c|}{25} & Heliox 50:50 & Non & 6 & 3 & No adverse effects were noted \\
\hline $\begin{array}{l}\text { Minamishima } \\
\text { 2011[65] }\end{array}$ & NO & $\begin{array}{l}\text { Mice aged 2-3 } \\
\text { months }\end{array}$ & 13 & 13 & $\begin{array}{c}\text { Air }+40 \mathrm{ppm} \\
\mathrm{NO}\end{array}$ & Air & 1 & 23 & $\begin{array}{l}\text { NO group had better } 10 \text { days survival rate }(11 / 13 \text { vs } 4 / 13) \text {. } \\
\text { NO largely prevented brain edema, as assessed by diffusion } \\
\text { weighted MRI } 24 \text { hours post CA. Neurological function score } \\
\text { at } 4 \text { days was also better in NO group. Moreover, NO had } \\
\text { ameliorated post-CA myocardial dysfunction, as assessed } 4 \\
\text { days after CPR by invasively measuring heart rate, maximum } \\
\text { rate of developed LV pressure (dP/dtmax), minimum rate of } \\
\text { developed LV pressure (dP/dtmin), cardiac output (CO), end- } \\
\text { systolic elastance (Ees), Ees/ arterial elastance (Ea), and the } \\
\text { time constant of isovolumic relaxation (T). }\end{array}$ \\
\hline Kida 2014[66] & NO & Mice & \multicolumn{2}{|c|}{51} & $\begin{array}{l}\text { TTM + } \\
10,20,40,60 \\
\text { or } 80 \text { ppm } \\
\text { NO }\end{array}$ & TTM & $30 \mathrm{~min}$ & 24 & $\begin{array}{l}40 \text { and } 60 \text { ppm groups had improved } 10 \text { d survival rates. This } \\
\text { improvement remained even when inhalation of } 40 \text { ppm NO } \\
\text { was delayed to } 2 \text { hours, but not to } 6 \text { hours post-CPR. } \\
\text { Moreover, MRI } 24 \text { hrs post-ROSC showed that } 40 \text { ppm NO + } \\
\text { TTM had less T2 intensity in brain stem and ventral } \\
\text { hippocampus than TTM only group. }\end{array}$ \\
\hline Brücken 2018[64] & NO & Rats & 13 & 7 & $\begin{array}{l}100 \% \text { O firs } \\
30 \% \text { and r } \\
\text { TTM for 6hrs } \\
\text { OR TTM }+ \\
20 \text { ppm NO }\end{array}$ & $\begin{array}{l}\text { hen reduced to } \\
\text { ndomized to } \\
\text { Normothermia } \\
\text { and no } \\
\text { treatment }\end{array}$ & 1 & 5 & $\begin{array}{l}\text { NDS were better in iNO+TTM than controls, while no } \\
\text { difference found between TTM and controls, or between } \\
\text { iNO+TTM and TTM alone. Histological analysis found no } \\
\text { difference between groups as well. }\end{array}$ \\
\hline NCT03079102[67] & NO & $\begin{array}{l}\text { Adult humans } \\
\text { within } 4 \text { hrs post- } \\
\text { ROSC }\end{array}$ & \multicolumn{2}{|c|}{130} & $\begin{array}{l}20 \mathrm{ppm}^{3} \mathrm{NO} \\
+\mathrm{N} 2\end{array}$ & N2 Only & ASAP & 12 & Ongoing \\
\hline Hayashida & $\mathrm{H} 2$ & Rats & \multicolumn{2}{|c|}{44} & $26 \% \mathrm{O} 2+$ & $26 \% \mathrm{O} 2+$ & $5 \mathrm{~min}$ & 2 & $\mathrm{H} 2+\mathrm{TTM}$ had the highest survival rate at day 7 post-ROSC \\
\hline
\end{tabular}




\begin{tabular}{|c|c|c|c|c|c|c|c|c|c|}
\hline $2014[80]$ & & & & & $\begin{array}{l}1.3 \% \mathrm{H} 2 \mathrm{OR} \\
26 \% \mathrm{O} 2+ \\
1.3 \% \mathrm{H} 2+ \\
\text { TTM OR } \\
26 \% \text { O2 + } \\
\text { TTM }\end{array}$ & normothermia & & & $\begin{array}{l}\text { (85.7\% vs } 71.4 \% \text { for } \mathrm{H} 2 \text { and TTM groups, and } 38.4 \% \text { for } \\
\text { controls). NDS scores at } 72 \text { hrs improved with } \mathrm{H} 2 \text { (H2+TTM } \\
90 \pm 68 \text {, TTM only } 217 \pm 74, \mathrm{H} 2 \text { group } 185 \pm 82 \text {, and control } \\
\text { 395 } \pm 40 \text { ). H2, with or without TTM, preserved the motor } \\
\text { activity and spatial memory as assessed by the Y-maze test } \\
\text { when compared to the control or TTM groups (even } \\
\text { comparable to the sham group) and decreased neuronal } \\
\text { damage assessed by number of NeuN-positive cells, level of } \\
\text { MAP2-immunoreactive dendrites, and quantity of lba1- } \\
\text { positive activated microglia/macrophages in the CA1. }\end{array}$ \\
\hline Wang 2016[81] & $\mathrm{H} 2$ & $\begin{array}{l}\text { Rats with non- } \\
\text { rhythmic } \mathrm{CA}^{4}\end{array}$ & $24 / g$ & 24 & $\begin{array}{c}2 \% \mathrm{H} 2 \mathrm{OR} \\
\text { TTM }\end{array}$ & No treatment & Immediate & 1 & $\begin{array}{l}\mathrm{H} 2 \text { group had higher } 96 \text {-hour survival rates than TTM and } \\
\text { control groups ( } 75.0 \% \text { vs } 45.8 \% \text { and } 33.3 \% \text {, respectively), } \\
\text { and better } 96 \text {-hrs NDS scores (145.6 } \pm 213.6 \text { vs } 311.0 \pm 210.9 \\
\text { and } 365.2 \pm 210.8 \text { ). Furthermore, cTnT release, LVEF, and } \\
\text { CW till 4hrs post-ROSC were better in H2 group than other } \\
\text { groups (except EF at } 1 \mathrm{hr} \text { and CW at } 4 \text { hrs vs TTM group). }\end{array}$ \\
\hline Tamura 2016[82] & $\mathrm{H} 2$ & Adult humans & \multicolumn{2}{|c|}{5} & $\begin{array}{c}2 \% \mathrm{H} 2 \\
\text { TTM }\end{array}$ & Non & $\begin{array}{c}\text { ICU } \\
\text { admission }\end{array}$ & 18 & H2 inhalation was safe and feasible \\
\hline Tamura 2017[83] & $\mathrm{H} 2$ & $\begin{array}{c}\text { Adult humans } \\
\text { with } \mathrm{GCS}<8\end{array}$ & \multicolumn{2}{|c|}{360} & $\begin{array}{l}\text { TTM }+2 \% \\
\mathrm{H} 2+24-50 \% \\
\quad \mathrm{O} 2\end{array}$ & $\begin{array}{c}\text { TTM + 24- } \\
50 \% \text { O2 }\end{array}$ & $\begin{array}{l}\text { ICU } \\
\text { admission }\end{array}$ & 18 & $\begin{array}{l}\text { Will primarily assess favorable } 90 \text {-day neurological outcome } \\
\text { (defined as CPC } 1 \text { or } 2 \text { ), and secondarily } 90 \text {-day survival rate, } \\
\text { survival time, GCS score, mRS, and MMSE results. }\end{array}$ \\
\hline Wei 2012[87] & $\mathrm{H} 2 \mathrm{~S}$ & $\begin{array}{l}\text { Rabbits with } \\
\text { asphyxic CA }\end{array}$ & 15 & 15 & 80 ppm H2S & No treatment & Immediate & 1 & $\begin{array}{c}\text { H2S group had smaller rise in plasma S100B levels } 1 \text {-hr post- } \\
\text { ROSC }(8.63 \pm 1.19 \mathrm{ng} / \mathrm{ml} \text { vs. } 10.85 \pm 1.44 \mathrm{ng} / \mathrm{ml}) \text {, lower NDS at } \\
24 \text { hrs, higher survival rate at } 7 \text { days }(83 \% \text { vs } 42 \%) \text {, more } \\
\text { preserved neuronal density and cell morphology of } \\
\text { hippocampal CA1, increased cerebral extraction of O2, } \\
\text { reduced arterio-jugular venous differences in glucose } \\
\text { concentration, and faster lactate clearance (suggesting earlier } \\
\text { transition from asphyxia induced anaerobic glycolysis to } \\
\text { oxidative phosphorylation). }\end{array}$ \\
\hline Geng 2015[88] & $\mathrm{H} 2 \mathrm{~S}$ & Rats & 37 & 47 & $\begin{array}{c}80 \mathrm{ppm} \mathrm{H} 2 \mathrm{~S} \\
+50 \% \mathrm{O} 2\end{array}$ & $50 \%$ O2 & 1 & 1 & $\begin{array}{l}\text { H2S group had lower increase in BBB permeability in both the } \\
\text { cortex and the hippocampus, lower brain water content } \\
(81.7 \% \pm 0.9 \% \text { vs } 84.8 \% \pm 0.6 \%) \text { within } 24 \text {-hours, better NDSs } \\
24-\text { hrs post-ROSC, decreased needed time to remove the } \\
\text { tape in the tape removal test (day } 1: 99 \text { [21-180] sec vs } 143 \\
\text { [98-180] sec, day } 3: 61 \text { [ } 17-180] \text { sec vs } 113 \text { sec }[33-180] \text { sec, } \\
\text { day } 14: 30 \text { [23-58] sec vs } 62[47-105] \text { sec), and increased } 14 \\
\text { days post-ROSC survival rates ( } 80 \% \text { vs } 50 \%) \text {. }\end{array}$ \\
\hline Wei 2015[89] & $\mathrm{H} 2 \mathrm{~S}$ & Rats & 11 & & $\begin{array}{l}50 \% \mathrm{O} 2+ \\
40 \mathrm{ppm} \mathrm{H} 2 \mathrm{~S} \\
\text { OR } 50 \% \text { O2 } \\
+80 \mathrm{ppm} \\
\quad \mathrm{H} 2 \mathrm{~S}\end{array}$ & $50 \%$ O2 & 1 & 1 & $\begin{array}{c}\text { H2S improved 14-d survival (40ppm:80\%, } 80 \mathrm{ppm}: 75 \% \text { vs } \\
\text { controls: } 50 \% \text { ) and tape removal test at day } 1,3 \text {, and } 14 \text {. It } \\
\text { also improved the number of surviving hippocampal CA1 } \\
\text { neurons as observed by HPF microscopy at d } 14 \\
\text { (40ppm: } 33 \pm 8,80 \mathrm{ppm}: 35 \pm 8 \text { vs controls: } 20 \pm 6 \text { ). Moreover, } \\
\text { H2S attenuated phosphorylation and translocation of NF-KB, } \\
\text { reflecting effective blockage NF-KB activation, and } \\
\text { (independent of dose) levels of iNOS, ICAM-1, TNF- } \alpha, \mathrm{IL}-1 \beta \\
\text { and IL- } 6 \text { response after ROSC. }\end{array}$ \\
\hline
\end{tabular}


1 Only statistically significant outcomes were tabulated. $(p<0.05)$.

2 These findings are consistent with current knowledge regarding the detrimental effects of post-ROSC fever ${ }^{[91,92]}$

$320 \mathrm{ppm}$ of $\mathrm{NO}$ is the accepted upper limit for human use.

4 Asphyxic CA differs significantly from dysrhythmic cardiac arrest in pathophysiologic mechanisms and response to therapy. ${ }^{[80]}$

Supplementary Table 2: Summary of the articles included in the study 